WATER-LEVEL CHANGES. IN THE HIGH PLAINS AQUIFER UNDERLYING PARTS OF

SOUTH DAKOTA, WYOMING, NEBRASKA, COLORADO, KANSAS, NEW MEXICO,

OKLAHOMA, AND TEXAS--PREDEVELOPMENT THROUGH NONIRRIGATION SEASON 1988-89

by Jack T. Dugan, Donald E. Schild, and William M. Kastner

U.S. GEOLOGICAL SURVEY

Water-Resources Investigations Report 90-4153

Lincoln, Nebraska

1990

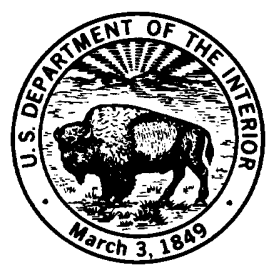


U.S. DEPARTMENT OF THE INTERIOR

MANUEL LUJAN, JR., Secretary

U.S. GEOLOGICAL SURVEY

Dallas L. Peck, Director

For additional information write to:

District Chief

U.S.Geological Survey 406 Federal Building 100 Centennial Mal1, North Lincoln, Nebraska 68508
Copies of this report can be purchased from:

U.S. Geological Survey Books and Open-File Reports Section Box 25425, Federal Center Denver, CO 80225-0425

[Telephone: (303) 236-7476] 


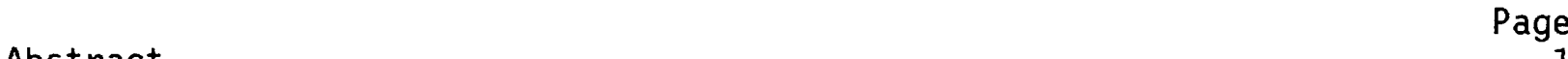

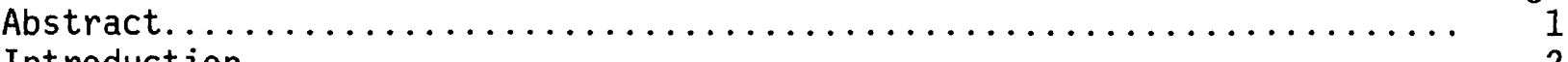

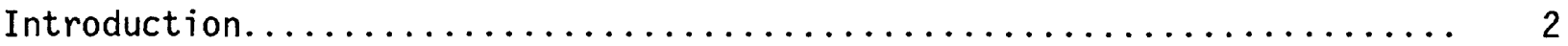

Extent and description of the High Plains aquifer............... 4

Factors affecting water-level change--recharge by precipitation and

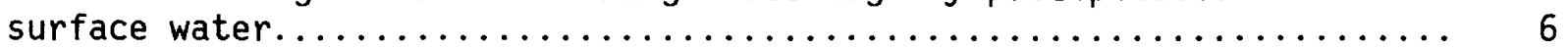

Factors affecting water-level change--natural discharge and ground-water

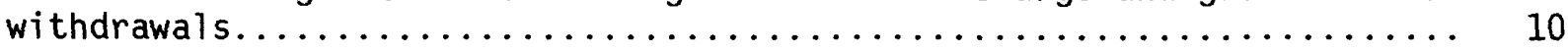

History of ground-water development and water-level changes in the High

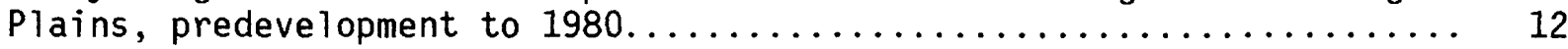

Observation-well locations in the High Plains and methods of data

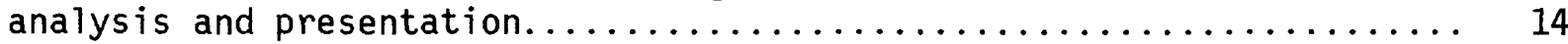

Water-level changes in the High Plains aquifer, 1980 to $1989 \ldots \ldots \ldots \ldots$

Precipitation in the High Plains, $1981-88 \ldots \ldots \ldots \ldots \ldots \ldots \ldots \ldots \ldots \ldots . \ldots \ldots$

Water-level changes in the High Plains aquifer, 1988 to $1989 \ldots \ldots \ldots 22$

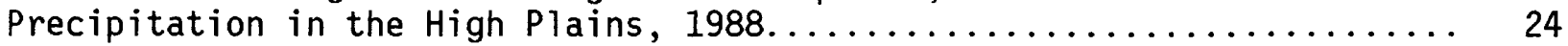

Representative hydrographs of three areas of intensive irrigation

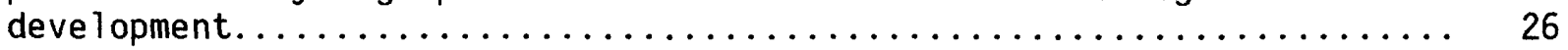

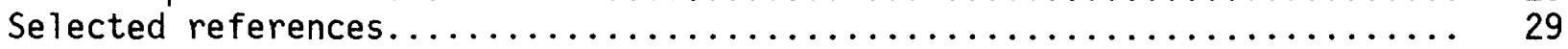

\section{FIGURES}

Figures 1-9. Maps showing:

1. Location and subdivisions of the High Plains aquifer... 3

2. Average annual precipitation and computed potential evapotranspiration, $1951-80 \ldots \ldots \ldots \ldots \ldots \ldots \ldots . \ldots . \ldots$

3. Ground-water withdrawals during 1985 , by county. Withdrawals for hydroelectric-power generation

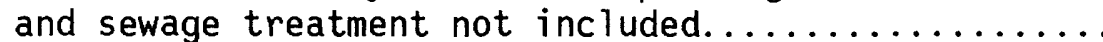

4. Water-level changes in the High Plains aquifer,

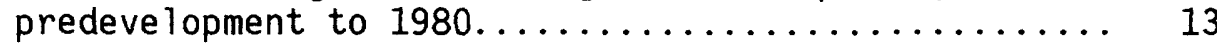

5. Location of wells where water levels were measured

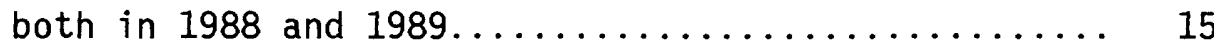

6. Water-level changes in the High Plains aquifer, 1980

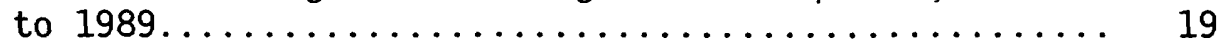

7. Mean annual 1981-88 departure from 30-year average

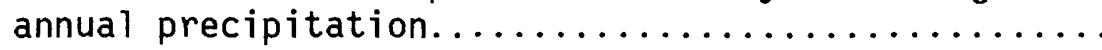

8. Water-level changes in the High Plains aquifer, 1988

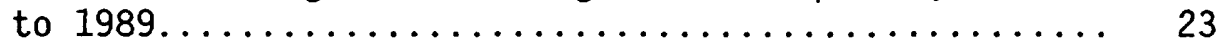

9. 1988 departure from 30-year average annual

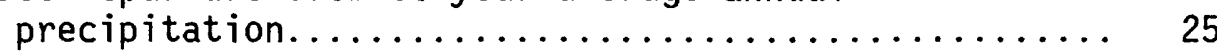

10. Graphs showing depth to water in representative wells: A, Seward County, Nebraska; B, Finney County, Kansas;

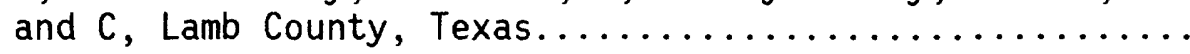




\section{TABLES}

Table 1. Characteristics of the High Plains aquifer.................... Page

2. Geologic units comprising the High Plains aquifer............ 5

3. Summary of observation wells measured and water-level change polygons, 1980 to 1989 and 1988 to 1989, by State, in the High Plains................................. 14

4. Water-level changes from 1980 to 1989 , by State........... 16

5. Water-level changes from 1988 to 1989 , by State............ 22

6. Average departure of precipitation in 1988 from the 30 -year

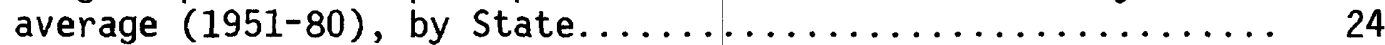

\section{CONVERSION FACTORS}

This report uses inch-pound units as the primary system of measurement. Inch-pound units can be converted to metric units by multiplying by the factors given in the following list.

Inch-pound unit

acre

acre-foot

foot

inch

mile

million gallons per day

square mile
Multiply by

$$
\begin{gathered}
0.4047 \\
1,233 \\
0.3048 \\
25.40 \\
1.609 \\
3,785 \\
2.590
\end{gathered}
$$

To obtain metric unit

hectare

cubic meter

meter

millimeter

kilometer

cubic meter per day

square kilometer

To convert degree Fahrenheit $\left({ }^{\circ} \mathrm{F}\right)$ to degree Celsius $\left({ }^{\circ} \mathrm{C}\right)$ use the following formula:

$$
{ }^{\circ} \mathrm{C}=5 / 9\left({ }^{\circ} \mathrm{F}-32\right) \text {. }
$$




\title{
WATER-LEVEL CHANGES IN THE HIGH PLAINS AQUIFER UNDERLYING PARTS OF SOUTH DAKOTA, WYOMING, NEBRASKA, COLORADO, KANSAS, NEW MEXICO, OKLAHOMA, AND TEXAS-- PREDEVELOPMENT THROUGH NONIRRIGATION SEASON 1988-89
}

\author{
by Jack T. Dugan, Donald E. Schild, and \\ William M. Kastner
}

\begin{abstract}
Changes in water levels in the High Plains aquifer underlying parts of South Dakota, Wyoming, Nebraska, Colorado, Kansas, New Mexico, Oklahoma, and Texas result from the variability of precipitation, land use, and ground-water pumpage. Water levels declined from the time aquifer development began until 1980 throughout much of the High Plains, except in South Dakota and Wyoming. From 1980 to 1989, water-level changes were variable, with declines ranging from 7.5 feet to more than 15 feet in the areas of intense irrigation deve1opment in Kansas, New Mexico, Oklahoma, and Texas. Large areas showing 7.5 to 15 feet of decline were present in northeastern Colorado, southwestern Nebraska, and in Box Butte County, Nebraska. Water levels were either stable or rising in the remaining areas of the aquifer, with some areas showing rises of more than 15 feet. The average area-weighted waterlevel change from 1980 to 1989 was a decline of 0.23 foot. A decrease in ground-water pumpage for irrigated agriculture was associated with above normal
\end{abstract}

precipitation throughout the High Plains during 1981 through 1988.

Water-level changes from 1988 to 1989 also were variable. Water levels continued to decline in most highly developed areas, rose only in scattered, isolated areas, and remained almost stable in more than half of the study area, where irrigation development was minimal. The average area-weighted change from 1988 to 1989 was a decline of 0.65 foot, which is larger than the change from 1980 to 1989. This decline was due to the large water-level declines in eastern Nebraska and most of Kansas that were related to below-normal precipitation and an increase in pumpage in irrigated areas.

The changes in water levels in the High Plains aquifer from 1980 to 1989 and from 1988 to 1989 are presented in maps. These maps were compiled from data obtained from U.S. Geological Survey and State data files. Water-level changes are discussed in relation to precipitation and ground-water irrigation. 


\section{INTRODUCTION}

\section{(Modified from Kastner and others, 1989)}

\section{Report on Water Levels in the High Plains} Aquifer is Requested by Congress.

The Omnibus Water Resources Development Act of 1986 (Public Law 99-662) amended the Water Resources Research Act of 1984 (Public Law 98-242). The amendment added a Title III to the legislation that states, in Section 306, that the U.S. Geological Survey in cooperation "...with the States of the High Plains region is authorized and directed to monitor the levels of the Ogallala [High Plains] aquifer, and report annually to Congress." Congress recognized that accurate information on the conditions and changes in the aquifer is necessary to make sound management decisions concerning the use of water, to predict future economic conditions, and to conduct hydrologic research pertaining to the High Plains.

The High Plains aquifer (formerly called the Ogallala aquifer) underlies one of the major agricultural areas in the United States (fig. 1). About 20 percent of the irrigated land in the United States is in the High Plains, and about 30 percent of the ground water used for irrigation in the United States is pumped from the High Plains aquifer (Weeks and others, 1988).

Many studies of parts of the aquifer have been completed by irrigation districts, local agencies, State agencies, the U.S. Geological Survey, and other
Federal agencies. A major study that examined the physical features of the entire aquifer recently has been completed by the U.S. Geological Survey. The High Plains Regional Aquifer-Systems Analys is (High Plains RASA) described the geology and hydrology of the aquifer in detail (Gutentag and others, 1984; Weeks and others, 1988). Computer models for each of three subdivisions of the High Plains (fig. 1) were developed during the study to simulate the effects of several proposed water-management practices on the aquifer. The analyses made as part of the High Plains RASA were based on data collected before 1981. Beginning in 1988, water-level data were again systematically collected and compiled in an aquifer-wide data base (Kastner and others, 1989). The U.S. Geological Survey and State and local agencies compiled water-level data collected since 1980 at more than 12,000 locations.

This report, the second in a series, was prepared to fulfill requirements of Section 306, Title III of Public Law 98-242 as amended. It describes the High Plains aquifer, the factors that affect water levels in the aquifer, the history of development of the aquifer, water-level changes from predevelopment through the nonirrigation season (generally October through March) of 1979-80 (herein referred to as predevelopment to 1980), water-level changes between the nonirrigation season of 1979-80 and nonirrigation season of 1988-89 (herein referred to as 1980 to 1989), precipitation patterns from 1981 through 1988, and water-level changes between the nonirrigation seasons of 1987-88 and 1988-89 (herein referred to as 1988 to 1989), and precipitation patterns for 1988 . The changes shown on the subsequent maps are supplemented by hydrographs of long-term water levels in selected wells. 


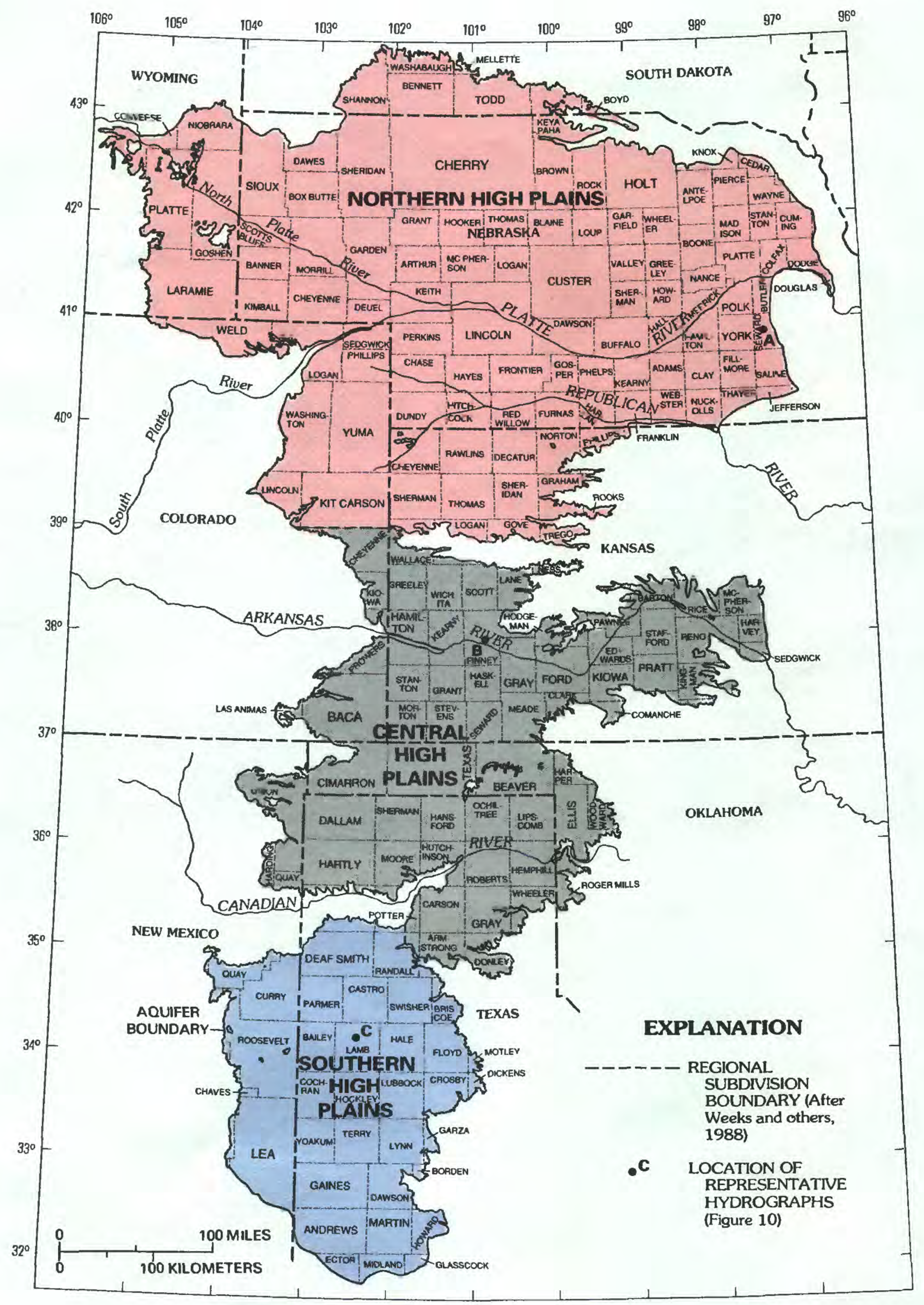

Figure 1.--Location and subdivisions of the High Plains aquifer. 


\section{EXTENT AND DESCRIPTION OF THE HIGH PLAINS AQUIFER}

(Modified from Kastner and others, 1989).

\author{
High Plains Aquifer Underlies Parts of \\ Eight States-South Dakota, Wyoming, \\ Nebraska, Colorado, Kansas, \\ New Mexico, Oklahoma, and Texas.
}

The principal source of water in the High Plains is ground water from saturated unconsolidated deposits. This source has been named both the "Ogallala aquifer" and the "High Plains aquifer"; the term "Ogallala aquifer" was used widely in the past. The High Plains aquifer consists mainly of one or more hydraulically connected geologic units of late Tertiary or Quaternary age with the Ogallala Formation normally the principal unit (Gutentag and others 1984, p. 8).

The High Plains aquifer underlies about 174,050 square miles in parts of South Dakota, Wyoming, Nebraska, Colorado, Kansas, New Mexico, Oklahoma, and Texas (table 1). The thickness of the aquifer ranges from less than 1 foot at the edge to as much as 1,300 feet in north-central Nebraska. The average saturated thickness is about 200 feet. The volume of water that will drain from the aquifer pore spaces differs throughout the area but averages about 15 percent of the total volume of saturated material. Therefore, the total volume of water that could drain from the aquifer would be about 3,250 million acre-feet (Gutentag and others, 1984). All of this water is not recoverable, however, because of economic constraints.

The High Plains is a remnant of an alluvial plain that once extended eastward from the ancestral Rocky Mountains. The formation of the plain was followed by periods of uplift when streams eroded the deposits near the mountain front. This erosion isolated the plain from the mountains in all areas except parts of Wyoming. In places, the original plain was dissected; elsewhere new sediments were deposited on the plain.

The oldest formation included in the High Plains aquifer is the Brule Formation (table 2), which consists mainly of well-cemented siltstone. In most areas, the ability of the Brule to transmit water generally is not sufficient to provide an economic supply of water to wel1s. In some areas, however, principally in parts of Colorado, Wyoming, and western Nebraska, the rock is fractured and yields adequate quantities of water to wells / and is considered a part of the High Plains aquifer. The Arikaree Group was deposited after the Brule formation and consists of massive fine-grained sandstone that generally does not yield large quantities of water.

The Ogallala Formation was deposited after the Arikaree Group by streams flowing from the ancestral Rocky Mountains. The Ogallala is the dominant formation in the High Plains aquifer over most of the High Plains and is composed of a variety of materials, including clay, silt, sand, and gravel.

Significant areas of sand dunes were formed on the older High Plains deposits. The largest of these areas are in the Sand Hills in north-central Nebraska where the deposits exceed 300 feet in thickness, and in Kansas south of the Arkansas River. The dunes are now stabilized by vegetation, but major dune formation continued until about 1,500 years before the present (Swinehart, 1989).

Quaternary streams eroded older formations and re-deposited the sediments as valley-fill material. Present-day streams continue to erode and deposit sediments. Where the sand dunes and stream deposits are saturated and are hydraulically connected to the High Plains aquifer, they are considered to be part of the High Plains aquifer. 
Table 1.--Characteristics of the High Plains aquifer

[Source: Gutentag and others, 1984]

\begin{tabular}{|c|c|c|c|c|c|c|c|c|c|c|}
\hline \multirow{2}{*}{ Characteristic } & \multirow{2}{*}{$\begin{array}{l}\text { Units of } \\
\text { measurement }\end{array}$} & \multirow{2}{*}{ Total } & \multicolumn{8}{|c|}{ Area of High Plains aquifer } \\
\hline & & & $\begin{array}{l}\text { South } \\
\text { Dakota }\end{array}$ & Wyoming & Nebraska & Colorado & Kansas & $\begin{array}{l}\text { New } \\
\text { Mexico }\end{array}$ & $\begin{array}{l}\text { Okla- } \\
\text { homa }\end{array}$ & Texas \\
\hline $\begin{array}{l}\text { Area covered by } \\
\text { aquifer. }\end{array}$ & Square miles & 174,050 & 4,750 & 8,000 & 63,650 & 14,900 & 30,500 & 9,450 & 7,350 & 35,450 \\
\hline $\begin{array}{l}\text { Percentage of total } \\
\text { aquifer area. }\end{array}$ & Percent & 100 & 2.7 & 4.6 & 36.6 & 8.6 & 17.5 & 5.4 & 4.2 & 20.4 \\
\hline $\begin{array}{l}\text { Percentage of each } \\
\text { State covered. }\end{array}$ & Percent & -- & 7 & 8 & 83 & 14 & 38 & 8 & 11 & 13 \\
\hline $\begin{array}{l}\text { Drainable water in } \\
\text { storage. }\end{array}$ & $\begin{array}{l}\text { Million } \\
\text { acre-feet }\end{array}$ & 3,250 & 60 & 70 & 2,130 & 120 & 320 & 50 & 110 & 390 \\
\hline
\end{tabular}

Table 2.--Geologic units comprising the High Plains aquifer

[Sources: Emry and others, 1987; Swinehart, 1989; Tedford and others, 1987]

\begin{tabular}{|c|c|c|c|c|c|c|c|c|c|c|}
\hline \multirow{2}{*}{$\begin{array}{l}\text { Geologic unit } \\
\text { comprising } \\
\text { the aquifer }\end{array}$} & \multirow{2}{*}{$\begin{array}{l}\text { Age and time } \\
\text { before present, } \\
\text { in million years }\end{array}$} & \multirow{2}{*}{ Composition } & \multicolumn{8}{|c|}{$\begin{array}{c}\text { Location where the unit is a significant part } \\
\text { of the High Plains aquifer }\end{array}$} \\
\hline & & & $\begin{array}{l}\text { South } \\
\text { Dakota }\end{array}$ & $\begin{array}{l}\text { Wyo- } \\
\text { ming }\end{array}$ & $\begin{array}{c}\mathrm{Ne}^{-} \\
\text {braska }\end{array}$ & $\begin{array}{l}\text { Colo- } \\
\text { rado }\end{array}$ & $\begin{array}{l}\text { Kan- } \\
\text { sas }\end{array}$ & $\begin{array}{l}\text { New } \\
\text { Mexico }\end{array}$ & $\begin{array}{l}\text { Okla- } \\
\text { homa }\end{array}$ & Texas \\
\hline $\begin{array}{l}\text { Valley-fill and } \\
\text { aluvial deposits }\end{array}$ & $\begin{array}{l}\text { Quaternary } \\
\text { (Holocene and } \\
\text { Pleistocene); } \\
1.8 \text { to present. }\end{array}$ & $\begin{array}{l}\text { Clay, silt, sand, } \\
\text { and gravel, } \\
\text { unconsolidated. }\end{array}$ & & & $x$ & & $x$ & & & \\
\hline Dune sand & $\begin{array}{l}\text { Quaternary } \\
\text { (Holocene); } \\
0.008 \text { to } 0.0015 .\end{array}$ & $\begin{array}{l}\text { Sand, very fine- } \\
\text { to medi um-grained, } \\
\text { windb lown. }\end{array}$ & & & $x$ & & $x$ & & & \\
\hline $\begin{array}{l}\text { Ogallala } \\
\text { Formation }\end{array}$ & $\begin{array}{l}\text { Tertiary } \\
\text { (Miocene); } \\
19 \text { to } 5 .\end{array}$ & $\begin{array}{l}\text { Clay, silt, sand, } \\
\text { and gravel gener- } \\
\text { ally unconsolidated } \\
\text { where cemented by } \\
\text { calcium carbonate, } \\
\text { forms mortar beds. }\end{array}$ & $x$ & $x$ & $x$ & $x$ & $x$ & $x$ & $x$ & $x$ \\
\hline Arikaree Group & $\begin{array}{l}\text { Tertiary } \\
\text { (Miocene and } \\
\text { 01igocene); } \\
29 \text { to } 19 .\end{array}$ & $\begin{array}{l}\text { Sandstone, very } \\
\text { fine- to fine- } \\
\text { grained, with beds } \\
\text { of volcanic ash, } \\
\text { silty sand, and } \\
\text { sandy clay. }\end{array}$ & $x$ & $x$ & $x$ & & & & & \\
\hline Brule Formation & $\begin{array}{l}\text { Tertiary } \\
\text { (01igocene); } \\
31 \text { to } 29 .\end{array}$ & $\begin{array}{l}\text { Siltstone, massive, } \\
\text { with beds of sand- } \\
\text { stone, volcanic ash, } \\
\text { and clay. }\end{array}$ & & $x$ & $x$ & $x$ & & & & \\
\hline
\end{tabular}




\section{FACTORS AFFECTING WATER-LEVEL CHANGE--RECHARGE BY PRECIPITATION AND SURFACE WATER}

Recharge to the High Plains Aquifer Is Affected by Climatic Conditions, Land Use, Vegetative Cover, and Soil Characteristics.

Water-level changes in an aquifer reflect the difference between recharge to and discharge from the aquifer. Almost all recharge to the High Plains aquifer originates naturally as infiltration of local precipitation. In a few isolated areas of the High Plains, however, recharge and rising water-table conditions have resulted from downward seepage of surfacewater irrigation or water diverted for hydroelectric power generation.

Ground-water recharge is a complex, dynamic process, and is dependent on the interaction of several variables. A simplified explanation for the recharge process is that recharge occurs when the amount of water infiltrating the soil exceeds the soil's available water capacity, and the excess water percolates beyond the root zone. In addition to the amount and seasonal patterns of precipitation, natural recharge is determined by variables that affect water consumption or loss from the soil. These include evapotranspiration, vegetation, land use, and soil characteristics.

The estimated average annual recharge rate in the High plains ranges from about 0.025 inch to about 6 inches (Weeks and others, 1988). These values compare favorably with simulated potential recharge rates for the 1951-80 period reported by Jack T. Dugan and Ronald B. Zelt of the U.S. Geological Survey (written commun., 1990) of less than 0.10 inch in the drier parts of the western High Plains to more than 6 inches in northeast Nebraska and central Kansas where soils are sandy. These recharge amounts represent from less than 0.5 percent to approximately 20 percent of the average annual precipitation (Jack T. Dugan and Ronald B. Zelt, U.S. Geological Survey, written commun., 1990). 
The recharge at any given location in the High Plains, however, may vary considerably from one year to the next, principally because of variations in precipitation. In many years, recharge may be negligible in those areas where average annual precipitation is low (Jack T. Dugan and Ronald B. Zelt, U.S. Geological Survey, written commun., 1990). Most of the long-term average recharge in these areas may actually take place following a few short wet periods. This process is often cyclical in the High Plains, with two or more consecutive years in which conditions are suitable for recharge, followed by several years when these conditions are not present, and recharge is negligible.

Average annual precipitation ranges from less than 14 inches along the western boundary of the High Plains to about 30 inches in eastern Nebraska and central Kansas (fig. 2). About 75 percent of the precipitation usually occurs during the growing season, from April to September. Precipitation during this season occurs mainly as local thunderstorms; therefore, irrigation requirements and recharge in a given time period may be quite variable.

The amount of water within the soil that becomes available for recharge is dependent on evapotranspiration. Potential evapotranspiration (fig. 2) is the theoretical measure of the climatic or atmospheric energy available for the removal of water from the soil either directly as evaporation or as transpiration from vegetation. Potential evapotranspiration represents the maximum water consumption that would occur from a field with complete vegetative cover, provided that an adequate supply of soil water were available at all times to meet the vegetation's demands. Potential evapotranspiration is dependent on various climatic or atmospheric elements, which include: solar radiation, temperature, humidity, and wind velocity. The increase in potential evapotranspiration from northeast to southwest across the High Plains is a consequence of (1) an increase in solar radiation, (2) an increase in temperature, (3) a decrease in humidity, and (4) an increase in wind velocity. The actual evapotranspiration or the amount of soil water actually consumed is further dependent on the type of vegetation, length of growing season, and the availability of soil water.

Perhaps of greatest significance to the occurrence of recharge is the seasonal relation between precipitation and evapotranspiration. In the High Plains, actual recharge is most likely to occur during short periods in the non-growing or dormant season when evapotranspiration demand upon the soil water is minimal and precipitation is allowed to accumulate in the root zone and percolate downward. This accumulative process during the dormant season may extend over a period of time, with late autumn precipitation remaining in the soil column during winter and percolating downward only after spring precipitation and winter snowmelt cause the soil's available water capacity to be exceeded. Thus, antecedent soil-water conditions, winter snow, and early spring precipitation prior to the onset of the growing season and the seasonal increase in evapotranspiration are critical to recharge during the dormant season. 
The hydrologic characteristics of the soils can have a significant effect on recharge and resultant water-level change. Areas with sandy soil tend to have much higher potential recharge. Under equivalent vegetation or crops and climatic conditions, recharge rates can be several times higher on sandy soils than on silty clay-loam soils, as a result of sandy soils' lower available water capacities and higher permeabilities (Jack T. Dugan and Ronald B. Zelt, U.S. Geological Survey, written commun., 1990). Slope affects recharge by affecting the rate at which precipitation infiltrates and becomes soil water. Soils with silty clayloam textures on steep slopes, common in parts of the High Plains, are characterized by high overland runoff and low infiltration during moderate to high-intensity rainfall. A more complete discussion and generalized map of the hydrologic characteristics of the soils and their relative effects on recharge in the High Plains is found in Dugan and others (1990).

Recharge also is affected by vegetation type and land use. Each vegetation or crop type has its own consumptive water requirement, which affects the soil water available for recharge and the irrigation needs. Therefore, variability in land use or crop types across the High Plains significantly affects patterns of water-level change.
Various government programs to remove cropland from production, including the Conservation Reserve Program, which was implemented in 1986 as part of the Food Security Act of 1985, have caused widespread, long-term changes in land-use patterns in the High Plains. Under the Conservation Reserve Program, cropland is returned to grassland or forest land for a minimum of 10 years. While the conversion of cropland to grassland in the High Plains may result in a decrease in recharge because of the larger water requirement for grasses (Luckey and others, 1980), the subsequent effects on water levels probably will be more than offset by decreases in ground-water withdrawals for irrigation as a result of these land-use changes.

Short-term or alternating land-use practices also affect recharge. The lack of vegetative cover on clean-tilled fallow or idle land results in minimal evapotranspiration losses. Some areas of documented water-level rises in the central and southern High Plains are related to the increased recharge as a result of these various land-use practices. Other tillage practices on dryland crops designed to prevent soil-water loss through capillary action and direct evaporation from soil may also enhance recharge. 


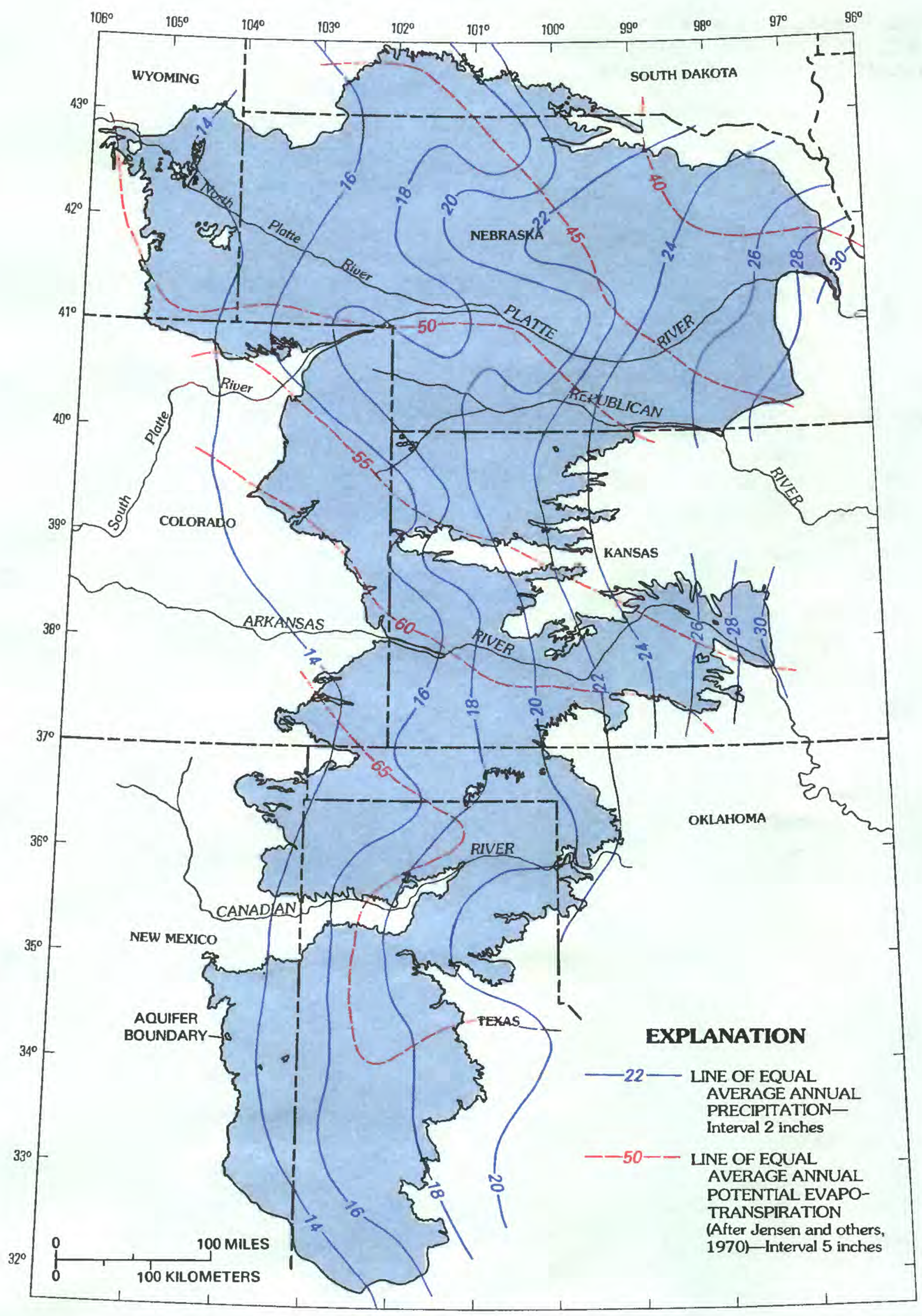

Figure 2.--Average annual precipitation and computed potential evapotranspiration, 1951-80. (Source: Jack T. Dugan and Ronald B. Zelt, written commun., 1990.) 


\section{FACTORS AFFECTING WATER-LEVEL CHANGE--NATURAL DISCHARGE AND GROUND-WATER WITHDRAWALS}

(Modified from Kastner and others, 1989)

\section{Discharge from the High Plains Aquifer Occurs Naturally by Evapotranspiration and Seepage to Streams, and Artificially Through Pumpage of Ground Water. During the 1980's, Ground-Water Pumpage Decreased in the High Plains.}

Water discharges from an aquifer naturally by evapotranspiration, where the water table is shallow, and by seepage to springs and streams. Water is artificially discharged from an aquifer principally by pumpage from wells. About 96 percent of the ground water pumped from the High Plains aquifer is for irrigation and other agricultural uses (Wayne Solley, U.S. Geological Survey, written commun., 1988). Other important uses of ground water in the High Plains are domestic consumption, mining, and industrial use.

The U.S. Geological Survey, in cooperation with State and local agencies throughout the country, has collected, stored, and published national water-use information at 5-year intervals since 1950 . The High Plains data from 1985 were used to compile a map (fig. 3) of ground-water withdrawals by county (U.S. Geological Survey, 1990). The values indicated in figure 3 were derived by dividing the total ground water used in the county by the area of the county.
The estimated total volume of water withdrawn from the High Plains aquifer for 1985 was $17,070,000$ acrefeet (Wayne Solley, U.S. Geological Survey, written commun., 1988). This estimate is based on extrapolation of metered pumpage, which generally represents a small percentage of the total pumpage; the extrapolation of estimated use per person or per head of livestock; and estimates of the water, supplemental to precipitation, required to raise crops.

Withdrawals of ground water from the High Plains aquifer in 1985 were about 19 percent less than in 1980 (Wayne Solley, U.S. Geological Survey, written commun., 1988). The decrease in ground-water withdrawals was due to several factors:

1. The volume and timing of precipitation during 1985 resulted in a requirement for less irrigation pumpage than in 1980. As an example, the supplemental water needed for raising irrigated crops in Nebraska was estimated to be 22 percent less in 1985 than in 1980 (Steele, 1988).

2. A reduction in agricultural commodity prices and increased irrigation costs and other production costs by 1985 made irrigation of crops less profitable.

3. Less water was required to fulfill irrigation requirements because of improved agricultural management practices. These practices included; minimum tillage, irrigation scheduling through increased knowledge of soil-water conditions, and improved plant varieties that utilized available soil water more efficientiy. 


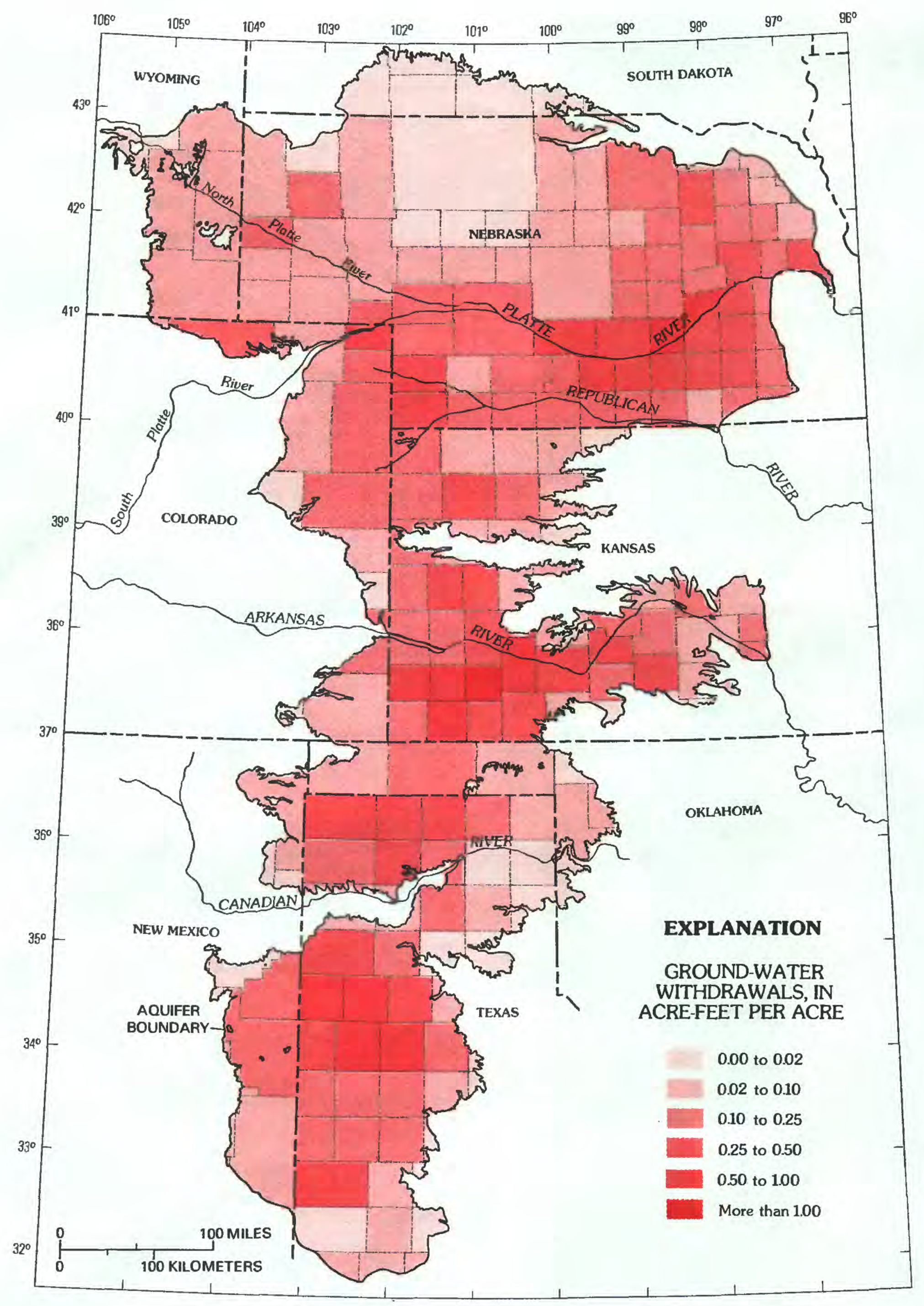

Figure 3.--Ground-water withdrawals during 1985 , by county. Withdrawals for hydroelectric-power generation and sewage treatment are not included. (Source: Withdrawal data from U.S. Geological Survey National Water Data Storage and Retrieval System.) 


\section{HISTORY OF GROUND-WATER DEVELOPMENT AND WATER-LEVEL CHANGES IN THE HIGH PLAINS, PREDEVELOPMENT To 1980}

(Modified from Kastner and others, 1989).

\section{Irrigation in the High Plains Largely Depends on Ground Water.}

An Army expedition headed by Major Stephen Long crossed part of the High Plains region in 1819-20. In the journals of the expedition the area was described as an "...extensive section of the country...almost wholly unfit for cultivation, and of course uninhabitable by a people depending upon agriculture for their subsistence..." (Dick, 1975). Contrary to this assessment, the High Plains has become one of the major agricultural regions of the United States.

Settlement of the High Plains was encouraged through incentives like the Homestead Act of 1862 and Railroad Land Grants following the Civil War. The subsequent development of railroads allowed settlers easier access to the region and made it easier for them to market their agricultural products. The major impetus for the intensive agricultural development of the region, however, was the availability of water for irrigation. The availability of surface water along some streams, such as the North Platte River, permitted irrigation in limited areas. Widespread irrigation development in the High Plains, however, depended on the availability of ground-water for irrigation.

Several factors have contributed to the increase in the use of ground-water for irrigation in the High Plains. Fluctuations in the climate were especially important. During droughts, many farmers switched from dryland farming to irrigation in order to maintain production. During and after the drought of the 1930's, ground-water irrigation increased, particularly in the southern High Plains. During the drought of the mid1950 's, irrigation expansion took place principally in the central and northern High Plains.

Fluctuations in the farm economy also have affected ground-water development. Increases in crop prices and decreases in well-drilling costs have stimulated increases in ground-water irrigation. Development of natural gas fields and rural electrification in the High Plains during the 1950's provided inexpensive energy for pumping and spurred irrigation development. An increase in energy costs that accompanied the "oil embargo" in the mid-1970's and an increase in pumping costs, caused partly by the lowering of water tables, have deterred additional development.

Another important factor in the increase of ground-water irrigation has been the changes in irrigation technology. Before 1900, ground-water withdrawal was by windmills from shallow, hand-dug wells. Improved drilling methods and the availability of gasolinepowered engines by the early 1900's allowed pumping from somewhat greater depths and opened new areas to ground-water irrigation. The development of more efficient turbine pumps by the early $1960^{\prime}$ s permitted costefficient pumping from water tables more than 100 feet below 1and surface (Weeks and others, 1988, p. A10). Also, in the 1960 's, center-pivot irrigation systems were introduced, which made it possible to irrigate areas bf sandier soils and steeper topography than could be irrigated with flood irrigation systems. With these advances in technology, ground-water development increased rapidly in the late 1960's and early 1970's, especially in the northern High Plains.

The development of the aquifer for irrigation has affected ground-water levels in most of the High Plains. Water-level changes from predevelopment to 1980 are shown in figure 4 (Weeks and others, 1988 , p. A14). Predevelopment water levels are those estimated to have existed before any effects imposed by human activity. In general, irrigation development had affected water levels in the southern High Plains by 1940 , the central High Plains by 1950 , and the northern High Plains by 1960 . In parts of north-central Nebraska, South Dakota, and Wyoming, ground-water levels still represent predevelopment conditions.

By 1980 , the greatest decline in water levels had occurred in the southern High Plains of New Mexico and Texas. I Water levels had declined more than 50 feet in a large part of this area with a maximum decline of nearly 200 feet in Texas. Water levels also had declined more than 50 feet in smaller areas of the central High Plains, in northern Texas, in the 0klahoma Panhandle, and in southwestern Kansas. In a few areas, predominantly in Nebraska, water levels rose as the result of recharge from surface-water irrigation and leakage from canals and reservoirs (Weeks and others, 1988). 


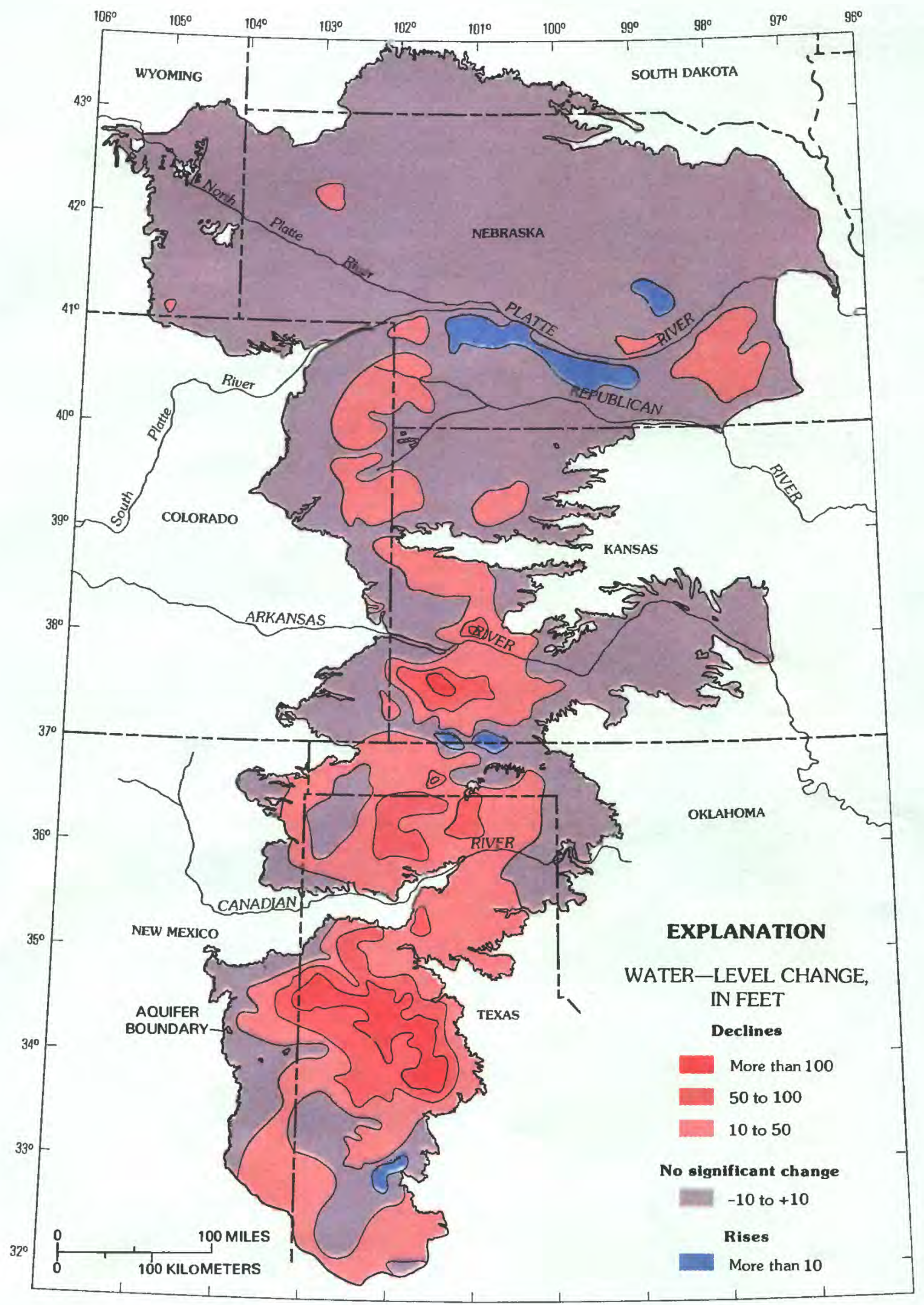

Figure 4.--Water-level changes in the High Plains aquifer, predevelopment to 1980 (modified from Weeks and others, 1988). 


\section{OBSERVATION-WELL LOCATIONS IN THE HIGH PLAINS AND METHODS OF DATA ANALYSIS AND PRESENTATION}

\section{Water-Level-Change Patterns Based on More Than 6,000 Observation Wells.}

Water-level changes are based on observations from 4,945 wells for the 1980 to 1989 period and 6,201 wells for the 1988 to 1989 period (table 3). The larger number of observation wells for the 1988 to 1989 period indicates an increase in wells measured since 1980. The locations of those wells measured in both 1988 and 1989 are shown in figure 5.

Table. 3--summary of observation wells measured and water-level change polygons, 1980 to 1989 and 1988 to 1989 , by state, in the High Plains

\begin{tabular}{|c|c|c|c|c|}
\hline \multirow[b]{2}{*}{ State } & \multicolumn{2}{|c|}{1980 to 1989} & \multicolumn{2}{|c|}{1988 to 1989} \\
\hline & $\begin{array}{l}\text { Number } \\
\text { of wells }\end{array}$ & $\begin{array}{r}\text { Number of } \\
\text { polygons }\end{array}$ & $\begin{array}{l}\text { Number } \\
\text { of wells }\end{array}$ & $\begin{array}{r}\text { Number of } \\
\text { polygons }\end{array}$ \\
\hline Colorado--.-- & 521 & 573 & 578 & 633 \\
\hline Kansas- & 975 & 1,049 & 1,259 & 1,343 \\
\hline Nebraska---... & 2,611 & 2,640 & 3,231 & 3,273 \\
\hline New Mexico-- - & 216 & 233 & 258 & 288 \\
\hline Oklahoma--...- & 303 & 326 & 382 & 406 \\
\hline South Dakota-- & 52 & 72 & 81 & 91 \\
\hline Texas--.-.-- & 243 & 323 & 370 & 459 \\
\hline Wyoming--.-- & 24 & 30 & 42 & 51 \\
\hline Totals & 4,945 & 5,246 & 6,201 & 6,544 \\
\hline
\end{tabular}

The density of water-level observation wells is governed principally by the degree of ground-water irrigation development. In the area of dense observation wells in central Nebraska, for example, more than 50 percent of all agricultural land, including range- 1and, is irrigated. Most areas of low observation-we11 density are those where ground-water irrigation development is minimal and there is little perceived need for water-level change information.

Polygons were defined to represent areas of equal water-level change according to the Theissen-polygon method (Theissen, 1911). In this method, the size and shape of a polygon is governed by the distance and location of other observation wells in respect to the well representing a particular polygon or area. Where observation wells are widely spaced, the polygons are large; conversely, where observation wells are closely spaced, the polygons are small. The use of polygons to depict areas of equal water-level change was deemed the most suitable method for short-term, nonuniformly distributed data.

The polygons depicting areas of equal water-level change for the two time periods are shown in figures 6 and 8 , respectively. The difference between the number of wells and the number of water-level change polygons indicated in table 3, for each State, is the result of polygons falling within more than one State and being counted more than once.

The area-weighted average by State for both waterlevel change and precipitation deviations presented in the tables in subsequent sections of this report was deemed more appropriate than the simple average of the observation point data. Where a large number of points represent a small area, the simple average would tend to over-represent changes or deviations in that area. The area-weighted value based on polygon size gives each unit area equal representation regardless of observation-well density.

Frequent abrupt differences in water-level changes that occur among adjacent polygons normally reflect contrasting hydrologic conditions at the observation wells representing each polygon. Variations in precipitation or ground-water withdrawals in the area surrounding an observation well may cause considerable variabllity in water-level change. 


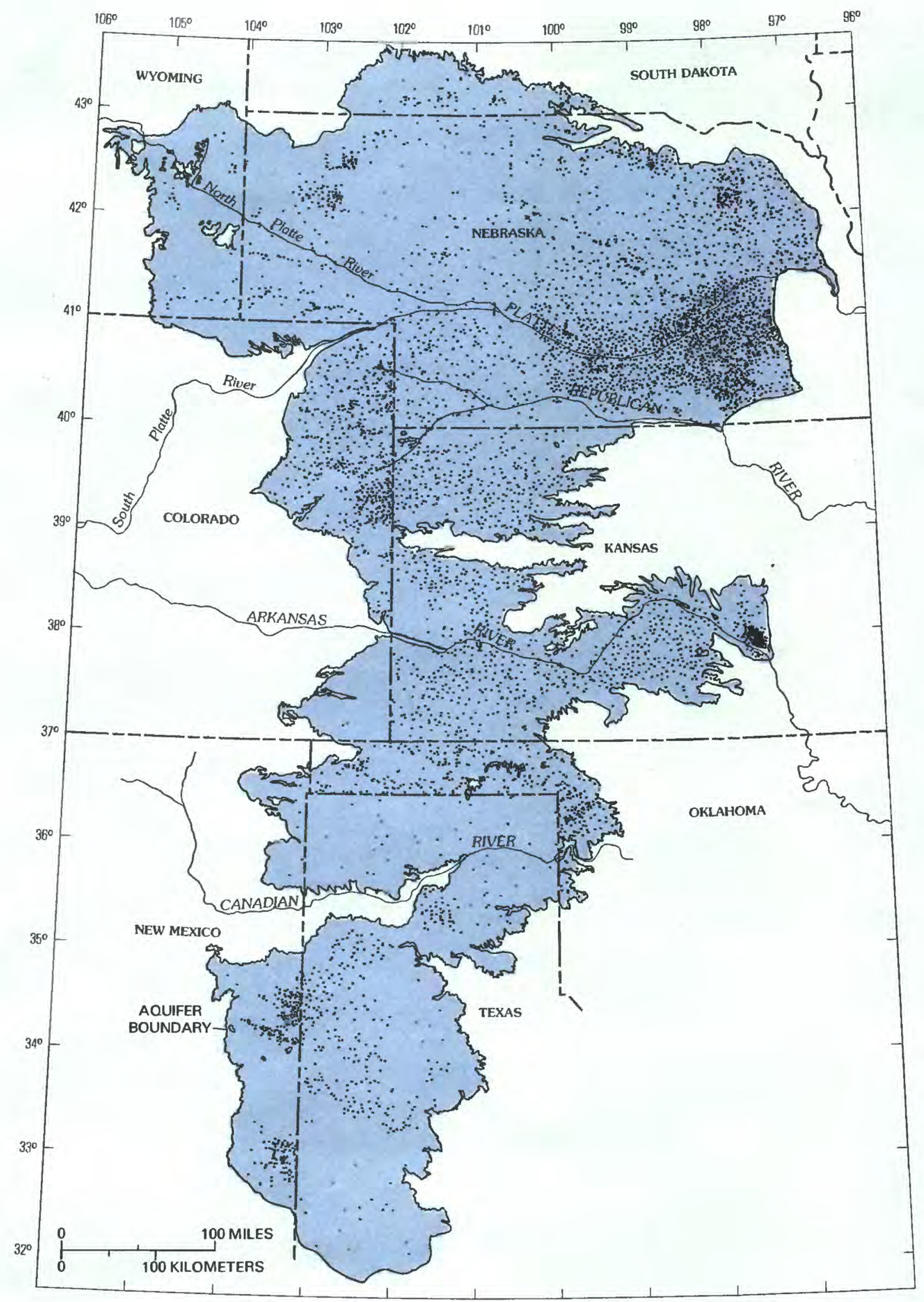

Figure 5.--Location of wells where water levels were measured both in 1988 and 1989 . 


\section{WATER-LEVEL CHANGES IN THE HIGH PLAINS AQUIFER, 1980 TO 1989}

Rate of Water-Level Declines Has Slowed in Much of the High Plains Aquifer since 1980.

Water-level change in the High Plains during the period 1980 to 1989 (fig. 6) was characterized by trends that were significantly different from predevelopment to 1980 (fig. 4). These more recent waterlevel-change trends are related to climatic conditions and to changes in irrigation practices and development.

Some areas with water-level declines from predevelopment to 1980 (fig. 4) became areas of waterlevel rises during 1980 to 1989 (fig. 6). The most significant areas of water-level trend reversal were in parts of the extreme southern High Plains of Texas and New Mexico; here, some areas that had declines by 1980 of up to 100 feet showed rises of over 15 feet from 1980 to 1989. Southeastern Nebraska, where widespread declines of 10 to 50 feet had occurred from predevelopment to 1980, had rises of 7.5 to 15 feet from 1980 to 1989.

Other areas which had shown significant declines from predevelopment to 1980 (fig. 4), continued to show declining water levels from 1980 to 1989. Parts of the Southern and Central High Plains in Texas, New Mexico, and southwest Kansas, which had predevelopment to 1980 declines exceeding 100 feet, had additional declines of more than. 15 feet from 1980 to 1989. Declines between 10 and 50 feet in a large area of intense irrigation development in northeastern Colorado and southwestern Nebraska by 1980 showed additional declines of 7.5 to 15 feet by 1989. Two other smaller areas in the northerh High Plains in the Nebraska Panhandle (Box Butte County) and in northwestern Kansas (Thomas and Sheridah Counties), which also were areas of 10 to 50-foot declines by 1980 , also showed further declines of 7.5 to 15 feet by 1989 .

Water

Water-level changes for each State within the High Plains are shown in table 4 . The average water-leve] decline in the High Plains from 1980 to 1989 was only 0.23 feet. Water-level changes in individual States were generally much more significant. Kansas, because of declines exceeding 15 feet in some areas, contributed to much of the overall water-level decline $(-4.61$ feet). Significant declines also were indicated in several parts of Colorado from 1980 to 1989, which contributed to the net decline in the High Plains aquifer.

Table 4.--Water-level changes from 1980 to 1989, by state

\begin{tabular}{|c|c|c|}
\hline & State & $\begin{array}{c}\text { Average area- } \\
\text { weighted change } \\
\text { (feet) }\end{array}$ \\
\hline \multirow{2}{*}{\multicolumn{2}{|c|}{$\begin{array}{l}\text { Colorado- } \\
\text { Kansas }\end{array}$}} & -1.45 \\
\hline & & -4.61 \\
\hline \multicolumn{2}{|c|}{ Nebraska- } & +1.34 \\
\hline \multicolumn{2}{|c|}{ New Mexico-n. } & -0.09 \\
\hline \multicolumn{2}{|c|}{ Okl ahoma- } & -0.36 \\
\hline \multicolumn{2}{|c|}{ South Dakota- } & -2.42 \\
\hline \multicolumn{2}{|c|}{ Texas } & +0.55 \\
\hline \multicolumn{2}{|c|}{ Wyoming-- } & +3.12 \\
\hline \multicolumn{2}{|c|}{ High Plains- } & -0.23 \\
\hline
\end{tabular}


An average water-level rise of 1.34 feet in Nebraska, largely offset the States with declines from 1980 to 1989. The Texas High Plains, an area of major declines prior to 1980 , showed a slight rise $(+0.55$ feet) in water levels between 1980 and 1989 .

The 0.23-foot water-level decline from 1980 to 1989 (table 4) represents a relatively small decrease in the total available water in storage in the High Plains aquifer. Considering that the High Plains aquifer extends over 174,050 square miles $(111,392,000$ acres) and approximately 15 percent $(0.15)$ of the saturated aquifer material can yield water by gravity drainage from pore spaces (Weeks and others, 1988), the decrease in available water in storage is approximately 3.8 million acre-feet. This represents an approximate 0.1 percent decrease in the drainable water in storage in the High Plains aquifer of 3,250 million acre-feet (table 1). This decrease in water in storage, however, is not uniformly distributed within the High Plains. Much of this decrease is concentrated in a few areas.

In most parts of the southern High Plains where water levels have continued to decline since 1980 , the rate of decline has been smaller than that during the period prior to 1980 . Assuming that water-level declines began in the southern High Plains of Texas and New Mexico in 1950, the average annual rate of decline between 1950 and 1980 was 3 to 4 feet. However, between 1980 and 1989, the rate of decline was 2 feet or less per year in most of these areas.

In the central High Plains, particularly southwestern Kansas, rates of water-level declines from 1980 to 1989 were slightly lower than the rate of decline from 1950 to 1980. Stanton, Grant, and Haskell Counties sustained widespread declines averaging approximately 75 feet from 1950 to 1980, an average decline of 2.5 feet per year. From 1980 to 1989 , additional declines averaged 20 feet in the three counties, or approximately 2.2 feet of decline per year.
In the northern High Plains, widespread waterlevel declines in northeastern Colorado and southwestern Nebraska prior to 1980 were relatively small. As a result of later irrigation development (mid- to late $1960^{\prime} \mathrm{s}$ ), declines were approximately 30 feet, or approximately 2.0 feet per year from 1965 to 1980 . Since 1980 , the rate of declines have averaged less than 1 foot per year in this area.

Two smaller areas of the northern High Plains, however, indicate rates of water-level declines from 1980 to 1989 near the pre-1980 rates. In the Nebraska Panhandle (Box Butte County), declines of nearly 30 feet occurred from 1950 to 1980 , a rate of 1.0 foot per year. From 1980 to 1989, declines in Box Butte County have continued at approximately 1.0 foot per year. In northwestern Kansas, principally Thomas and Sheridan Counties, where declines began in about 1965 , the. rate of decline prior to 1980 was nearly 1.3 feet per year. From 1980 to 1989, additional declines averaging 10 feet occurred in the two counties, a rate of approximately 1.1 feet per year.

The area in south-central Nebraska of water-level rises of 50 feet or more prior to 1980 , resulting from seepage losses from surface-water irrigation, has decreased in size since 1980 . The western part of this area no longer appears as an area of significant rise and shows some areas of decline from 1980 to 1989. Ground-water irrigation and efforts to control seepage losses in these areas have reversed these rises. Only in the eastern part of this area (Gosper and Phelps Counties) are rises continuing at a rate of 1.5 to 2 feet per year.

Small areas of rise prior to 1980 in the extreme southern High Plains are continuing to rise at a rate exceeding 1 foot per year. Areas of rise along the Kansas-0klahoma border prior to 1980 are now declining at a rate of approximately 1 foot per year. 
Several factors contributed to rising water levels or lower rates of decline during the 1980 to 1989 period:

(1) The years 1980 to 1989 represent a period of generally above-normal precipitation throughout the High Plains, which resulted in conditions favorable for increased recharge and lower irrigation requirements.

(2) Irrigation-management practices that require less water have gained acceptance since 1980. Practices such as irrigation scheduling based on soil-water conditions, construction of water-reuse pits to capture runoff, and adoption of more drought-resistant crop varieties have contributed to more efficient irrigation applications. Consequently, irrigation pumpage has declined while achieving comparable crop yields.

(3) Economic considerations have dictated reduction in ground-water withdrawals for irrigation. The relative decline or stabilization of commodity prices and a continuing rise in production costs, including energy costs for pumpage, have caused reductions in pumpage and further irrigation development. In some areas of the High Plains, where large water-level declines have occurred, irrigated cropland has been reverted to dryland crops because of prohibitive pumping costs resulting from decreasing well yields. The increasing costs of well installations and distribution systems have been a further deterrent to additional development.

(4) Large water-level declines in some areas prior to 1980 prompted local controls on irrigation. State and local agencies in some areas were granted the authority to monitor and regulate pumpage volumes from existing wells and limit new well construction.

(5) Major expansion of irrigated cropland peaked by 1980. Few large areas that are well-suited hydrologically or on the basis of soil or topography remain to be developed. In addition, widespread long-term droughts, which often stimulate expansion of irrigated cropland, did not occur in the High Plains during the $1980^{\prime}$ s. 


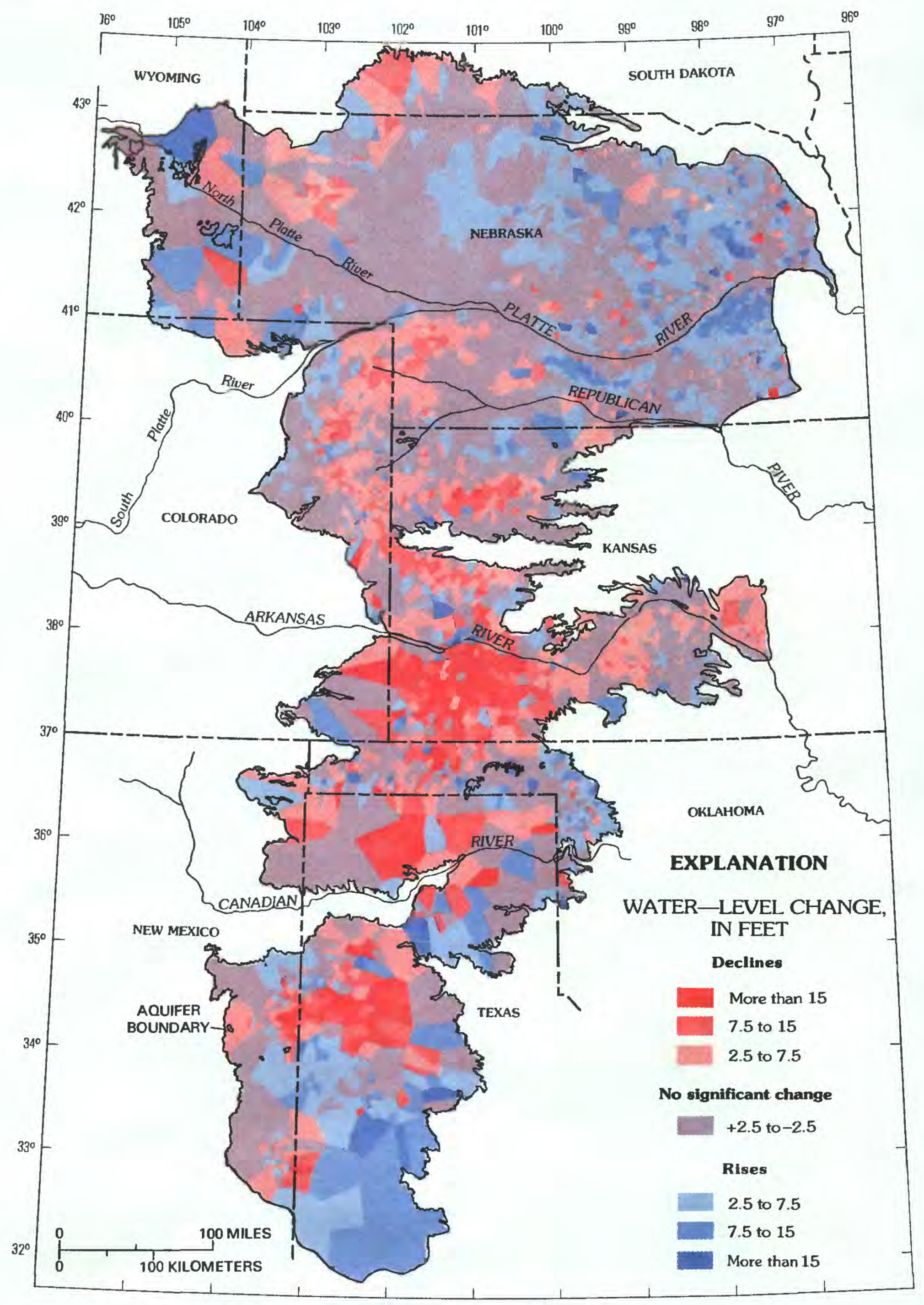

Figure 6.--Water-level changes in the High Plains aquifer, 1980 to 1989. 


\section{PRECIPITATION IN THE HIGH PLAINS, $1981-88$}

\section{Above-Normal Precipitation Contributes \\ to Water-Level Rises in Many Parts of the High Plains.}

Annual precipitation values in the High Plains, for the period 1981 through 1988 (fig. 7), are derived from observations at more than 200 National Weather Service stations. The patterns depicted in figure 7 are based on Theissen polygons constructed around each of these stations. The values represent the average departure for 1981 through 1988 from the annual averages (normals) computed for each of the sites for the 30-year period, 1951-80.

The rise in ground-water levels in several areas of the High Plains from 1980 to 1989 (fig. 6) can be attributed largely to above-normal precipitation (fig. 7). Only a few small areas had below-normal precipitation, the most extensive of these being in parts of northwestern Kansas and the Nebraska Panhandle. Nearly all other areas with below-normal precipitation are represented by single stations. of those areas with below-normal precipitation, all but one were within 2 inches of the normal.

Two large areas had above-normal precipitation for the period 1981 through 1988. A continuous area extending from eastern Nebraska into south-central South Dakota had precipitation which averaged from 2 to more than 6 inches above normal. Water-level rises of 2.5 to 7.5 feet were common throughout this area, with discontinuous areas of 7.5 to 15 feet of rise. The second large area encompasses most of the southern High Plains. Annual precipitation in this area averaged from 2 to more than 6 inches above normal. These were areas where water-leve 1 rises of 7.5 to 15 feet were common, exceeding 15 feet in several smaller areas.

Throughout most of the remainder of the High Plains, annual precipitation averaged slightly (0-2 inches) to moderately (2-4 inches) above normal from 1981 through 1988. Isolated areas in southeastern Wyoming, extreme northwestern Kansas, south-central Kansas, and western 0k1ahoma were from 4 to 6 inches above normal. Associated patterns of water-level changes, however, were quite variable in these areas.

Generally, areas showing water-level rises or lower rates of decline from 1980 to 1989 (fig. 6), as compared with predevelopment to 1980 water-level changes| (fig. 4), mostly were areas with higherthan-average precipitation. Areas where rates of water-level decline were still large generally were those of slightly below to slightly above normal precipitation, as a comparison of figures 6 and 7 indicates. Some areas, such as parts of south-central South Dakota and the central High Plains, however, had significant water-level declines in spite of abovenormal precipitation. The intensive irrigation deve1opment and pumpage in some of these areas account for the continuing declines. Restrictive recharge conditions or low ground-water-storage capacity may account for some of the declines where irrigation pumpage is onfy moderate (see fig. 3 ).

Caution should be exercised in interpreting waterlevel change in direct relation to precipitation. Deviations in precipitation do not directly correspond to variations in ground-water recharge, nor do they indicate irrigation-pumpage requirements. The complex relations among precipitation, evapotranspiration, vegetation, soils, and the underlying geologic materials need to be taken into consideration in understanding the changes in ground-water storage, particularly in intensively irrigated areas. 


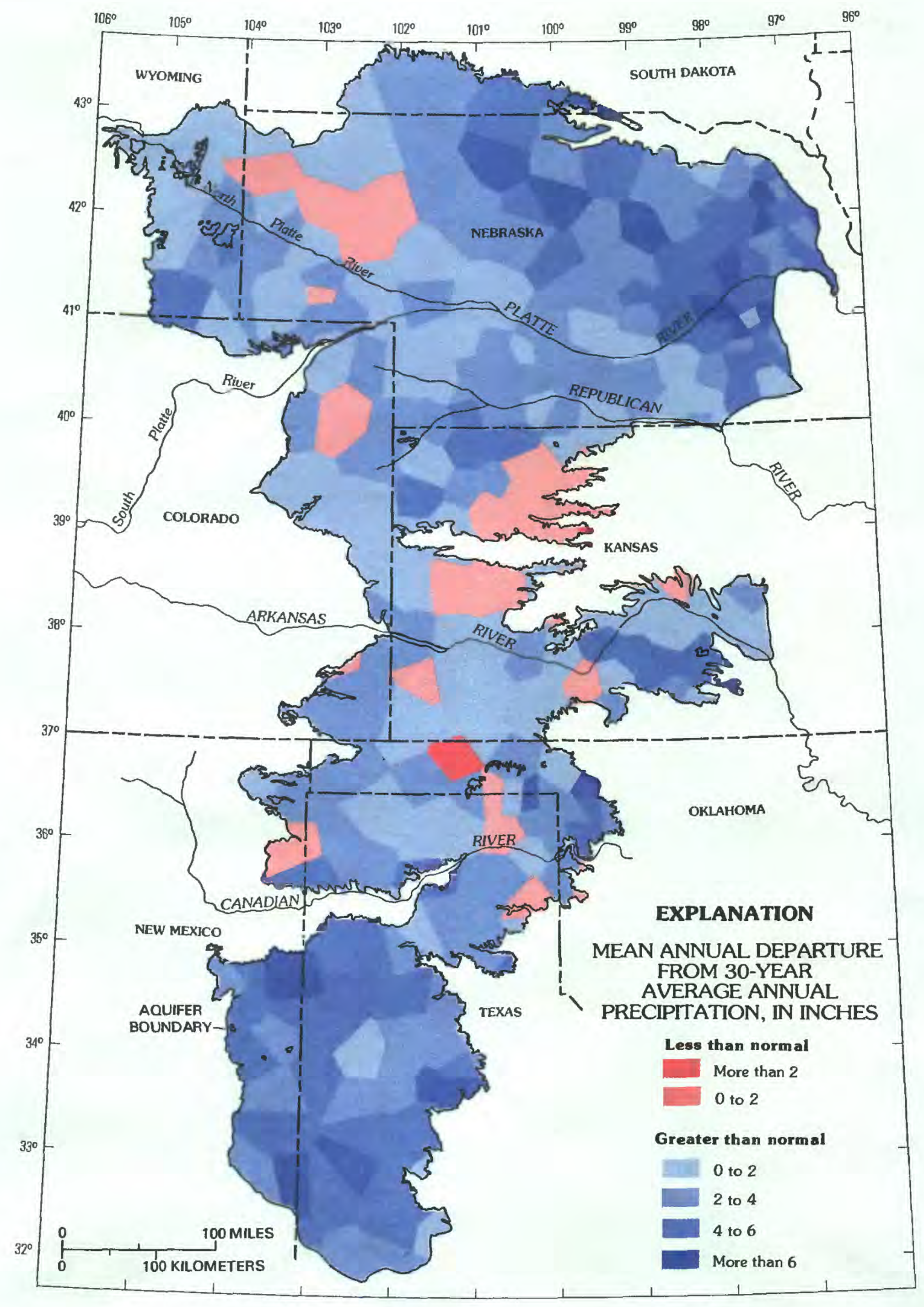

Figure 7.--Mean annual 1981-88 departure from 30-year average annual precipitation. (Source: U.S. Department of Commerce, National Climatic Data Center.) 


\section{WATER-LEVEL CHANGES IN THE HIGH PLAINS AQUIFER, 1988 TO 1989}

\author{
Water Levels Decline in Many Parts \\ of the Northern and Central \\ High Plains, but Continue to \\ Rise in Parts of the Southern \\ High Plains.
}

Water-level changes in the High Plains from 1988 to 1989 (fig. 8) generally differ from those waterlevel-change patterns of the previous year (1987 to 1988) reported by Kastner and others (1989). The most distinctive water-level changes from 1988 to 1989 were the declines prevalent in several areas of the northern and central High Plains and rises in much of the southern High Plains.

The most significant areas of declining water levels were in eastern Nebraska and parts of central and southwestern Kansas, where declines of 1 to 3 feet were common. Several isolated locations in these areas had declines of 3 to 5 feet and some exceeding 5 feet. Other smaller areas of decline occurred in parts of southeastern Wyoming and the eastern High Plains of Texas.

Discontinuous areas of substantial water-level rises in the central and southern High Plains extend from extreme southwestern Kansas to the extreme southern High Plains of Texas. Only isolated areas of water-level rises occurred in the northern High Plains, generaliy in areas of minimal ground-water irrigation.

A comparison of the 1988 to 1989 water-level changes with the longer term changes from 1980 to 1989 indicated different patterns. The 1980 to 1989 rises, ranging from 2.5 to more than 15 feet in eastern and central Nebraska, contrasted with water-level declines observed from 1988 to 1989. In general, areas of rise throughout most other parts of Nebraska, especially in the north-central part of the State from 1980 to 1989 , were areas of decline or little change from 1988 to 1989. However, in southwestern Nebraska, in some areas of extensive ground-water irrigation, declines of nearly 7.5 to 15 feet from 1980 to 1989 reversed in 1988 to 1989; here, isolated rises occurred from 1988 to 1989 .

The widely occurring declines in southwestern Kansas from 1980 to 1989, which exceeded 15 feet in some cases, continued over most of the area from 1988 to 1989 , with additional declines of 5 feet or more. As indicated previously, some isolated areas of rise, however, did occur in this area from 1988 to 1989. An area of relatively stable water-table conditions in central Kansas from 1980 to 1989 showed significant declines from 1988 to 1989.

The areas of general rises in water levels from 1980 to 1989 in the Texas and New Mexico High Plains were also characteristic of changes from 1988 to 1989. The area of declines of 15 feet or more from 1980 to 1989 in the north-central Texas Panhandle was also generally an area of declines from 1988 to 1989. The rather complex patterns of water-level change in the
Oklahoma Panhandle from 1980 to 1989 also were evident during 1988 to 1989.

The general rises in water levels over much of the High Plains in Wyoming from 1980 to 1989 were. largely areas of water-level decline from 1988 to 1989. Areas of rise in northeastern Colorado from 1980 to 1989 showed little change from 1988 to 1989.

Water-level changes in the High Plains States are summarized in table 5 for the 1988 to 1989 period. Much of the overall water-level decline from 1988 to 1989 resulted from declines in Kansas and Nebraska. These declines were only slightly offset by small rises in New Mexico and Texas. Using an average of 15 percent (0.15) recoverable water from pore spaces (Weeks and others, 1988) and 174,050 square miles in the High Plains aquifer (table 1 ), the water in storage in the High Plains aquifer was reduced by approximately $10,900,000$ acre-feet, or about 0.3 percent of the total available water in storage $(3,250 \mathrm{million}$ acre-feet).

Table 5.--Water-1eve1 changes from 1988 to 1989 , by state

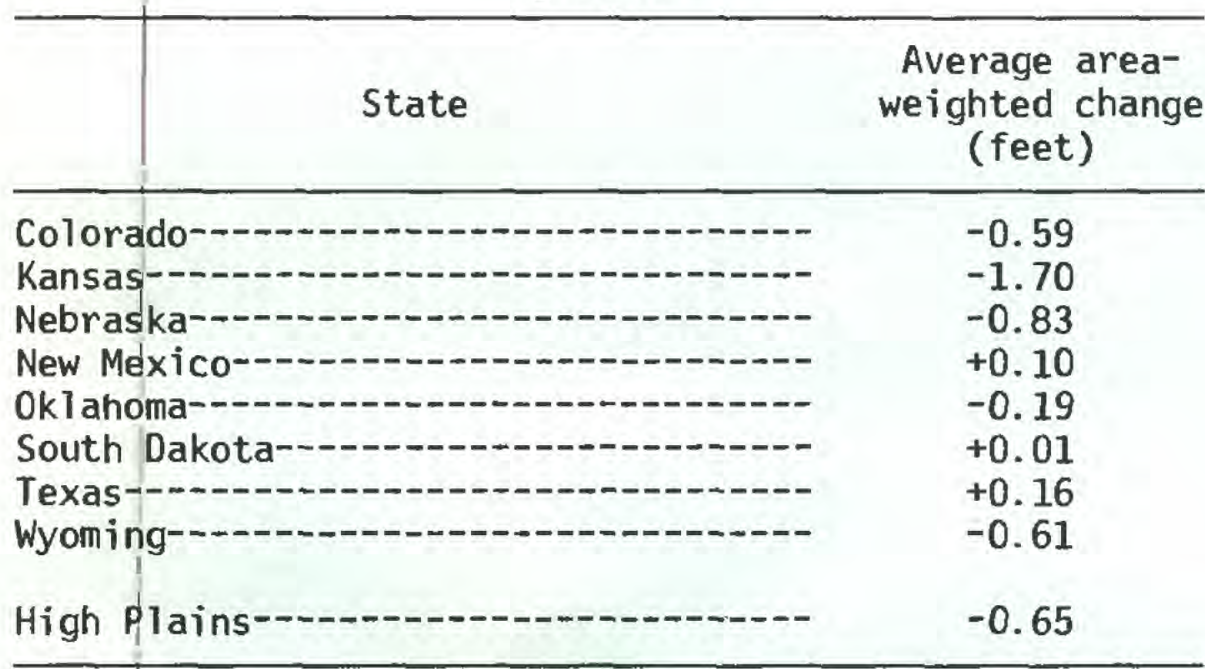

Caution should be taken in the interpretation of anomalous 1 -year deviations in water-levels that are apparent from figure 8 . Some of these may represent observation errors, but are more likely to represent hydrologic conditions specific to a given area. Among those conditions that may contribute to these anomalies are:

(1) Local hydrologic conditions that differ significantly from those of surrounding areas.

(2) Intense, local development of irrigation within a larger area of minimal development.

(3) Surface-water irrigation or stream diversions for hydroelectric power generation with large seepage losses from canals and reservoirs.

(4) Temporary shifts in land-use or cropping patterns, such as substantial areas of irrigated cropland replaced by fallow or dryland crops.

These conditions may result in only temporary deviations in regional water-level patterns of change, but could indicate the initial phase of a developing trend in a given area. 


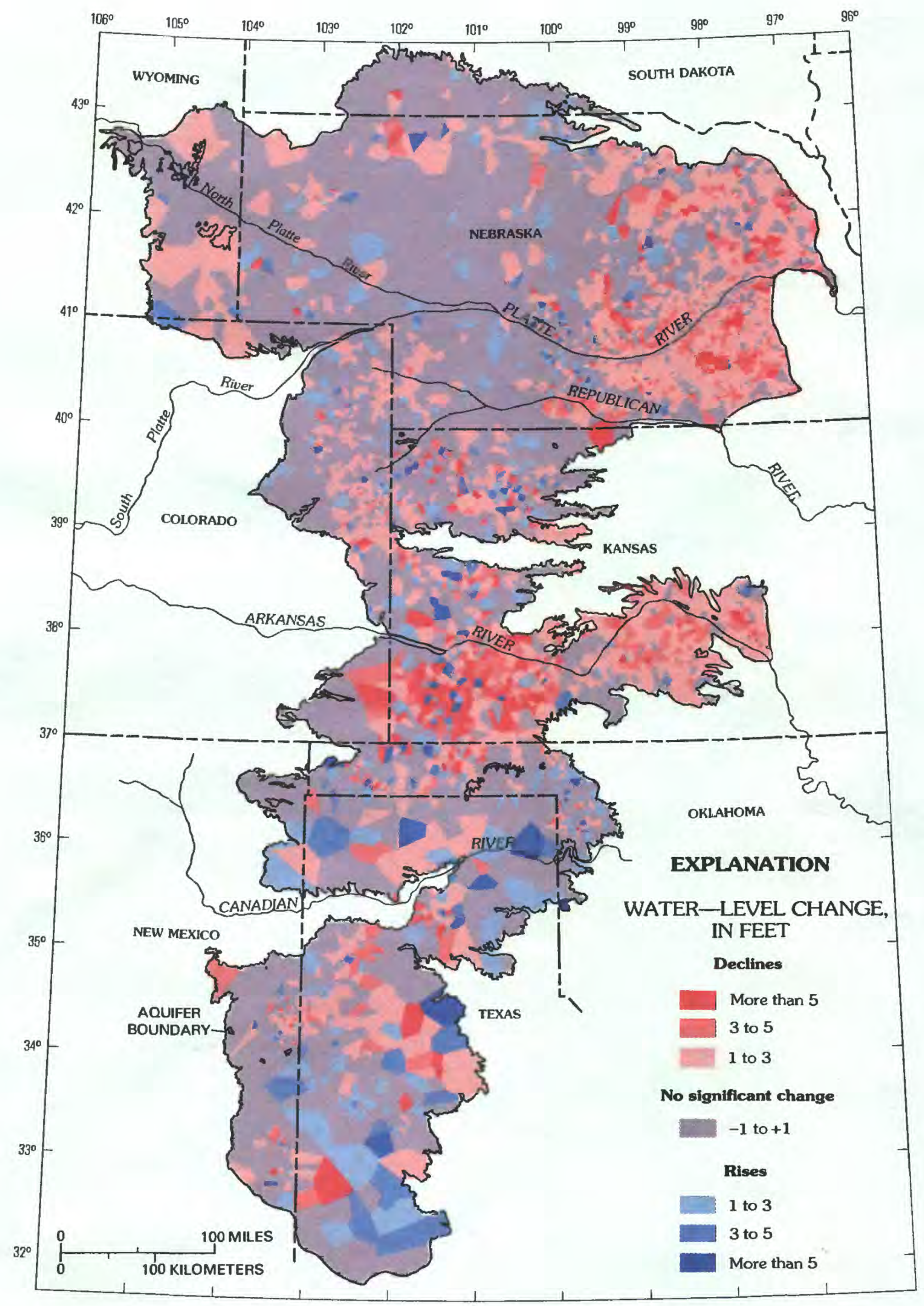

Figure 8.--Water-level changes in the High Plains aquifer, 1988 to 1989. 


\section{PRECIPITATION IN THE HIGH PLAINS, 1988}

\section{Precipitation Extremely Variable in the High Plains during 1988.}

Precipitation in the High Plains for 1988 was measured at more than 200 National Weather Service stations. The precipitation patterns shown in figure 9 are based on Theissen polygons constructed around each of these stations. The values represent the 1988 departures from the annual averages computed for each of the stations for the 30-year period, 1951-80. The 30-year average annual precipitation for the High Plains is shown in figure 2 .

Precipitation across the High Plains in 1988 indicates deviations in both directions from the 30-year average (fig. 9). The largest positive departure was 11.60 inches at a station in New Mexico. The largest negative departure was 13.01 inches at a station in Kansas. Table 6 summarizes the average departure of precipitation in 1988 from the 30-year average, by State.

Table 6.--Average departure of precipitation in 1988 from the 30-year average (1951-80), by state

\begin{tabular}{lc}
\hline State & $\begin{array}{c}\text { Average area- } \\
\text { weighted departure } \\
\text { (inches) }\end{array}$ \\
\hline Colorado- & +0.32 \\
Kansas & -4.01 \\
Nebraska & -0.62 \\
Oklahoma- & +5.75 \\
South Dakota- & +0.91 \\
Texas- & +1.23 \\
Wyoming- & +2.09 \\
High Plains aquifer- & -1.42 \\
\hline
\end{tabular}

Regionally, precipitation in the eastern parts of the northern and central High Plains, particularly central Kansas and eastern Nebraska, was considerably below normal, with deficits of 5 to 10 inches over most of this area. Several sites in this area were more than 10 inches below normal, or approximately 60 percent of the average annual precipitation. The significant water-level declines in these areas (fig. 8) correspond closely to those areas of below-normal precipitation.

In contrast, annual precipitation in parts of the southern and north-central section of the northern High Plains (fig. 9) exceeded the 30-year average by 5 to 10 inches. The area represented in New Mexico with precipitation more than 10 inches above normal, exceeded the annual average for that area by nearly 80 percent. The above-normal precipitation in the southern High Plains coincides with water-level rises in that section during 1988.

Selasonal variability in precipitation (not shown) affected the 1988 to 1989 water-level changes in figure 8. Precipitation in the cool season, JanuaryMarch and October-December 1988, was generally below normal throughout the High Plains. Central Kansas and eastern Nebraska appeared to have been the most deficient in cool-season precipitation, averaging 2 to 4 inches below normal, with some areas more than 4 inches below normal. Precipitation in the southern High Plains area also was generally 2 to 4 inches below normal for the cool season. Thus, the cool season, typically the season. most conducive for recharge because of low evapotranspiration demands, was relatively dry.

Most of the regional variability in the 1988 precipitation (fig. 9) resulted from deviations in precipitation during the growing season, April through September. In the southern High Plains, growing-season precipitation was generally from 4 to 8 inches above normal, with some areas in New Mexico and Texas exceeding normal seasonal precipitation by more than 8 inches. The water-level rises in 1988 resulted, at least in part, from a reduction in irrigation requirements and ground-water pumpage during the growing season because of the above-normal precipitation. Even though little soil water generally is available during the growing season for recharge in the High Plains, some soil-water surpluses may have occurred in areas of above normal precipitation in the southern High Plains.

The eastern part of the northern and central High Plains, including central Kansas and eastern Nebraska, however, was characterized by large precipitation deficits in the growing season, with amounts from 4 to 8 inches below seasonal normals. In addition, daily growing-season temperatures in this area averaged more than 2 degrees Fahrenheit above normal, which would increase evapotranspiration. The effect of increased irrigation requirements as a result of precipitation deficits and higher evapotranspiration is apparent in the substantial water-level declines in this region. 


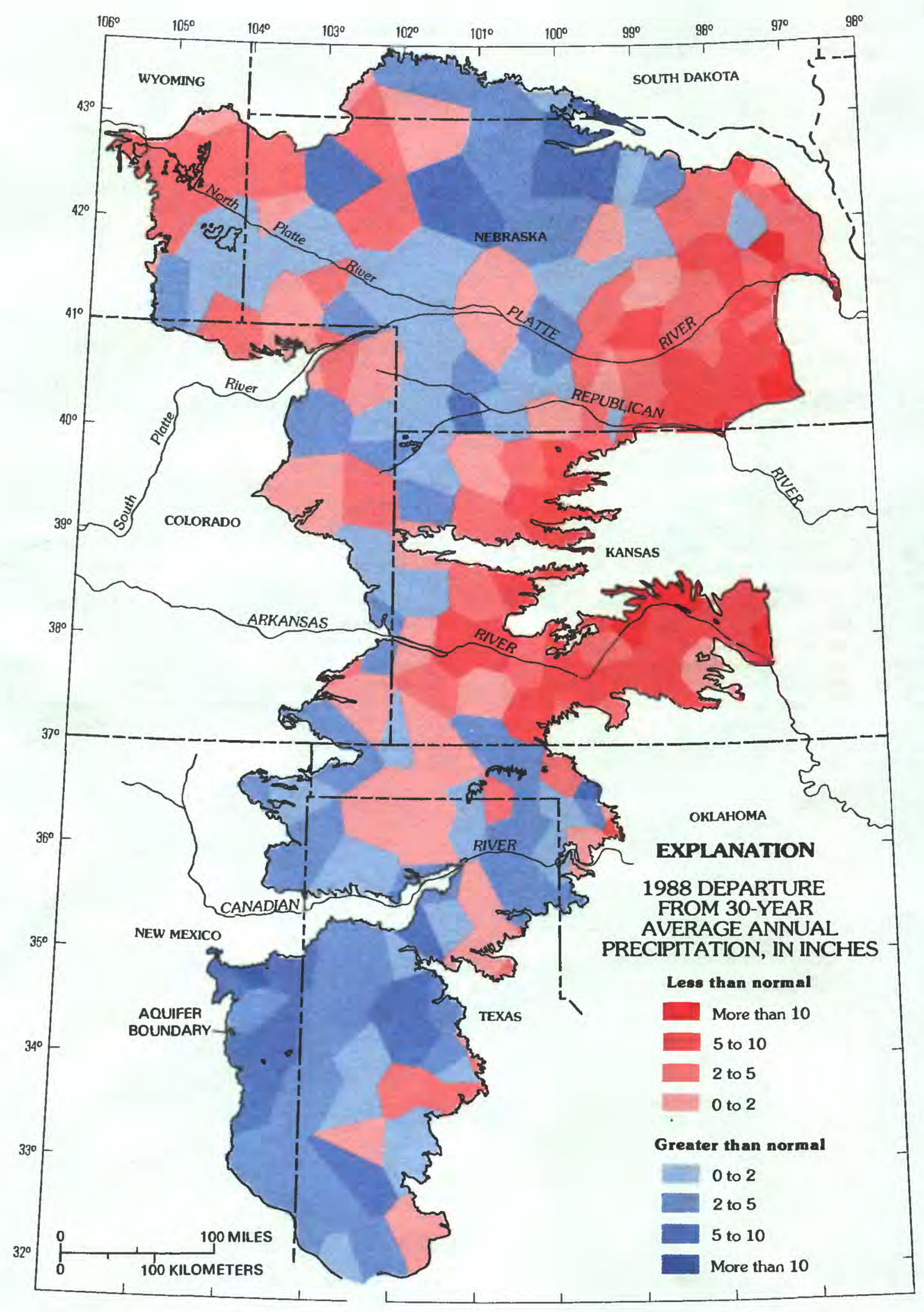

Figure 9. --1988 departure from 30-year average annual precipitation. (Source: U.S. Department of Commerce, National Climatic Data Center.) 


\section{REPRESENTATIVE HYDROGRAPHS OF THREE AREAS OF INTENSIVE IRRIGATION DEVELOPMENT}

\author{
Water Levels Decline in Three \\ Areas of Intensive Irrigation \\ Development in 1989.
}

Hydrographs of observation wells representing different geographic areas (fig. 1) and hydrologic conditions within the High Plains are shown in figure 10. The area surrounding each observation wel1 represents different aquifer, climatic, soil, and agricultural conditions; therefore, each hydrograph shows different water-level responses through time to these variable conditions. Average precipitation (fig. 2) alone accounts for substantial differences in long-term potential recharge and irrigation pumpage requirements in the area surrounding each observation well.

Water levels in the observation well in southeastern Nebraska (Seward County) (fig. 10A) represent conditions where the High Plains aquifer is composed of permeable sand and gravel. In most parts of this area, water levels in the aquifer rise rapidly in response to precipitation. Development of ground water for irrigation has been intensive since the mid-1950's. Within a 1 -mile radius of this observation well, there are 10 irrigation wells. Water levels in the aquifer decline rapidly when these wells are pumped, but they recover quickly following the irrigation season. The rise in the water table from 1982 to 1988 is the cumulative effect of the above-normal precipitation and the trend toward more efficient water use. A decline in water levels of approximately 2 feet from the 1988 peak to the 1989 peak can be attributed to the below-normal precipitation in 1988, which was more than 7 inches below normal.

The hydrograph of the well in southwestern Kansas (Finney County) (fig. 10B) shows a relatively uniform decline of water levels in response to intensive irrigation beginning in 1949. Irrigation in this area increased rapidly after World War II when largecapacjty turbine pumps were introduced. Since the early 1950's, pumpage of ground water for irrigation has more than offset natural recharge (precipitation) and the decrease in natural discharge from streams in the area. Consequently, ground water is being continually removed from storage. The smaller rate of waterleve1 decline from 1983 through 1987 can be attributed to the increase in precipitation and decrease in acres irrigated from 1983 through 1987 . This smaller rate of decline continued through 1989, even though the 1988 annual precipitation was 5 to 10 inches below normal in the area, which could be the result of the long-term reduction in acres irrigated in the area since 1983 (Kastner and others, 1989).

The hydrograph for the observation well in the southern High Plains of Texas (Lamb County) (fig. 10C) represents a relatively typical pattern of water-level declines and changes in irrigated agriculture in this part of the High Plains of Texas. The hydrograph also represents a long-term, gradual decline in water levels untill the mid-1980's, when the rate of decline decreased. The smaller rate of water-level decline sincel 1985 can be attributed to (1) a reduction in irrigated acreage, (2) improvement and implementation of more efficient irrigation equipment, and (3) better management and conservation practices (Larry F. Land, U.S. Geological Survey, written commun., 1990). In addition, annual precipitation since 1980 (fig. 7) has been approximately 4 inches above normal in this general area. 

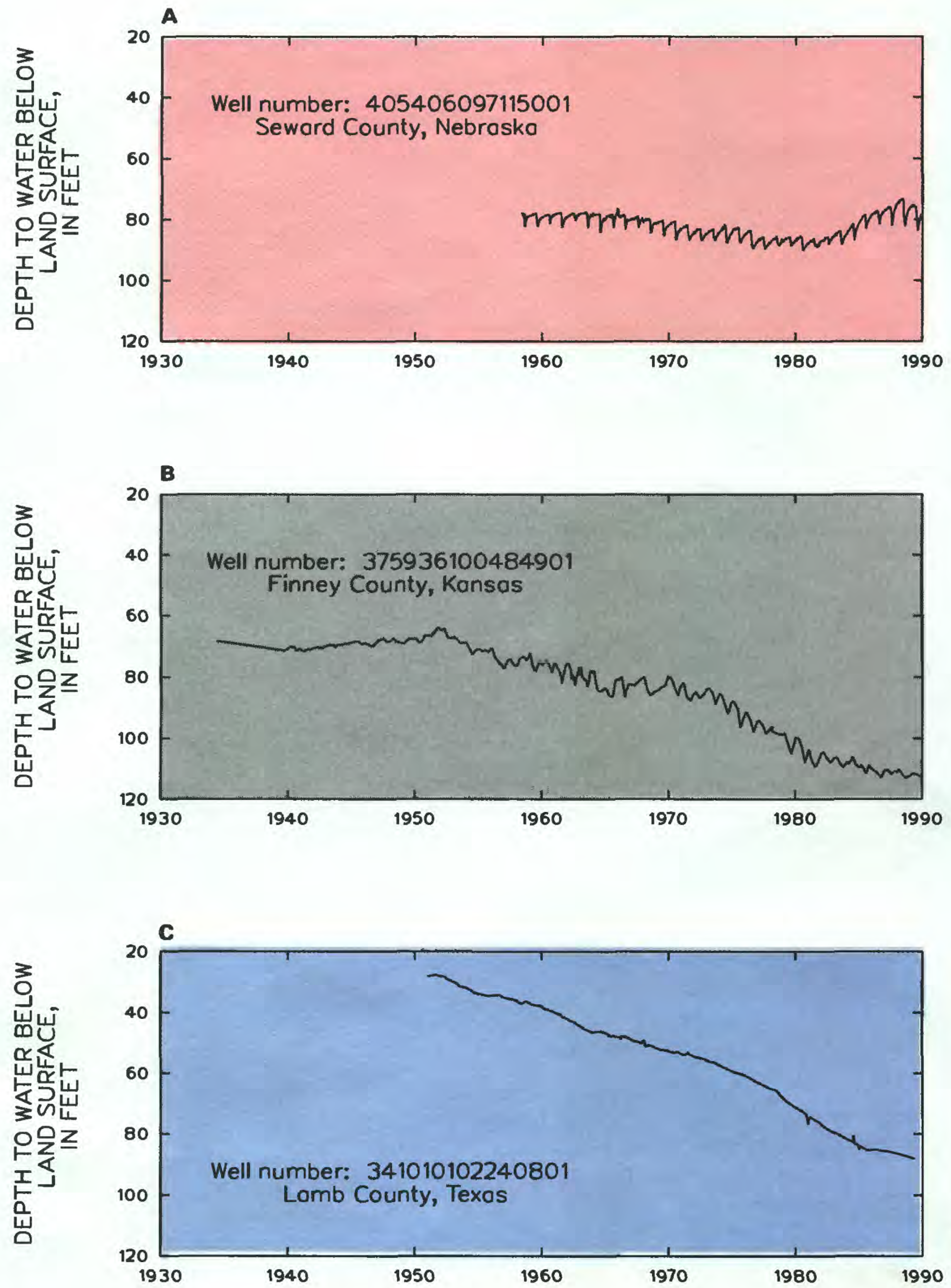

Figure 10.--Depth to water in representative wells: A, Seward County, Nebraska; B, Finney County, Kansas; and $C$, Lamb County, Texas. 